\title{
Comparative chromato-mass spectrometric study of tinctures based on Echinacea purpurea (L.) Moench
}

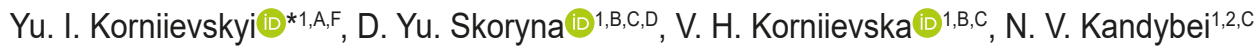 \\ 'Zaporizhzhia State Medical University, Ukraine, ${ }^{2}$ PJSC VIOLA Pharmaceutical Factory, Zaporizhzhia, Ukraine
}

A - research concept and design; B - collection and/or assembly of data; C - data analysis and interpretation; D - writing the article; $\mathrm{E}$ - critical revision of the article; $\mathrm{F}$ - final approval of the article

An urgent problem today is the spread of secondary immunodeficiencies associated with increased stress, urbanization, and negative changes in the environment that lead to impaired immune function. Herbal remedies are milder, less likely to become addictive and have side effects, and are long-lasting. A promising plant with immunomodulatory action is Echinacea purpurea (L.) Moench, a member of the family Asteraceae. The main active ingredients of echinacea are phenolic compounds, carbohydrates, and alkylamides. The chemical composition of echinacea is also represented by flavonoids, tannins, saponins, higher fatty acids, amino acids, betaine, essential oil, macro- and microelements (Se, Co, $\mathrm{Ag}, \mathrm{Mo}, \mathrm{Zn}, \mathrm{Mg}, \mathrm{K}, \mathrm{Na}$, Fe, etc.). Drugs have immunostimulatory, antioxidant, membrane-stabilizing effect, promote healing of wounds, burns, ulcers, are used in infectious and viral diseases, especially HF. They are traditionally used for furunculosis, septicemia (infection of the blood), pyorrhea, tonsillitis, especially for the treatment of boils, carbuncles, and abscesses. It is also important that in modern pharmaceutical science the leading place is occupied by research related to the introduction into medical practice of herbal medicines, the study of their chemical composition, standardization, development of optimal technologies for the manufacture of phytopreparations. That is why the objects of our research were tinctures based on Echinacea purpurea.

The aim of the work is to study and compare the component composition of tinctures based on Echinacea purpurea (L.) Moench using gas chromatography (GC).

Materials and methods. Tinctures of rhizomes with roots of Echinacea purpurea were used for the study: experimental - made according to industrial technological recipe (1:5, extractant - ethanol $70 \%$ ) from raw materials harvested in July 2019 at the research site of Zaporizhzhia State Medical University and control - finished products LLC "Zhytomyr Pharmaceutical Factory", series 20319. Tinctures were investigated on a gas chromatograph Agilent 7890B with mass spectrometric detector 5977B. The NIST14 mass spectrum library was used to identify the components.

Results. 31 (experimental) and 23 (control) components were identified by GC in rhizomes with rhizomes of Echinacea purpurea. The results of the study indicate that the qualitative and quantitative chemical composition of rhizomes with roots of Echinacea purpurea was characterized by complexity and variability. This fact complicates the process of standardization of phytopreparations and can affect their effectiveness and safety. Therefore, members of the genus Echinacea should be the subject of further in-depth chemical study.

Conclusions. A comparative analysis of the component composition of tinctures based on Echinacea purpurea (L.) Moench was studied and performed with the help of GC. The GC method is suitable for the determination of natural BAS in the composition of phytopreparations from echinacea and can be used in the development of methods for their standardization. The results of the study were of value for further development and improvement of analytical regulations for raw materials and phytopreparations from Echinacea purpurea. They can also be the basis for the creation of new substances with immunomodulatory activity based on the underground organs of echinacea.

Key words: gas chromatography, Echinacea, component composition, immunomodulatory action.

Current issues in pharmacy and medicine: science and practice 2021; 14 (3), 275-281

\section{Порівняльне хромато-мас-спектрометричне дослідження настойок на основі Echinacea purpurea (L.) Moench}

\section{Ю. І. Корнієвський, Д. Ю. Скорина, В. Г. Корнієвська, Н. В. Кандибей}

Актуальною проблемою є поширення вторинних імунодефіцитів, пов'язаних із підвищеними стресовими навантаженнями, урбанізацією та негативними змінами в екології, що призводять до порушень функціонування імунної системи. Препарати, які виробляють на основі лікарських рослин, характеризуються більш м'якою дією, меншою імовірністю розвитку звикання та побічних ефектів, а також можливістю доволі тривалого застосування. Ехінацея пурпурова (Echinacea purpurea (L.) Moench), представник родини Asteraceae, - перспективна рослина з імуномодулювальною дією. Основними діючими речовинами ехінацеї є фенольні сполуки, вуглеводи й алкіламіди. Хімічний склад ехінацеї включає також фрлавоноїди, дубильні речовини, сапоніни, вищі жирні кислоти, амінокислоти, бетаїн, ефірну олію, макро- та мікроелементи ( $\mathrm{Se}, \mathrm{Co}, \mathrm{Ag}, \mathrm{Mo}, \mathrm{Zn}, \mathrm{Mg}, \mathrm{K}$, Na, Fe тощо). Лікарські препарати чинять імуностимулювальну, антиоксидантну, мембраностабілізувальну дії, сприяють загоєнню ран, опіків, виразок; їх застосовують при інфекційних і вірусних захво-

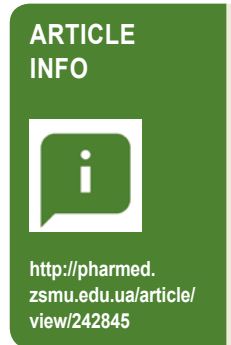

UDC 615.451.16:582.998.1].074:543.544 DOI: $10.14739 / 2409-2932 \cdot 2021 \cdot 3 \cdot 242845$

Current issues in pharmacy and medicine: science and practice 2021; 14 (3), 275-281

Key words: gas chromatography, Echinacea, component composition, immunomodulatory action.

*E-mail: kornievsk@gmail.com

Received: 20.09.2021 // Revised: 05.10.2021 // Accepted: 11.10.2021 
рюваннях, особливо верхніх дихальних шляхів. Традиційно їх використовують при фурункульозі, септицемії (зараженні крові), піореї, тонзилітах, а також для лікування фурункулів, карбункулів та абсцесів. У сучасній фармацевтичній науці провідне місце посідають дослідження, пов'язані з впровадженням у медичну практику лікарських засобів рослинного походження, вивченням їхнього хімічного складу, стандартизацією, розробленням оптимальних технологій виготовлення фітопрепаратів. Тому об'єкти наших досліджень - настойки на основі ехінацеї пурпурової.

Мета роботи - вивчення та порівняльний аналіз компонентного складу настойок на основі ехінацеї пурпурової (Echinacea purpurea (L.) Moench) за допомогою газової хроматографії (ГX).

Матеріали та методи. Для дослідження використали настойки кореневищ із коренями ехінацеї пурпурової: експериментальна, виготовлена за промисловою технологічною рецептурою (1:5, екстрагент - етанол 70 \%) із сировини, що заготовлена в липні 2019 року на дослідній ділянці Запорізького державного медичного університету; контрольна - готова продукція ТОВ «Житомирська фрармацевтична фабрика», серія 20319. Настойки досліджували на газовому хроматографрі Agilent 7890B із мас-спектрометричним детектором 5977В. Для ідентифрікації компонентів використана бібліотека мас-спектрів NIST14.

Результати. За допомогою ГХ у настойках кореневищ із коренями ехінацеї пурпурової ідентифікували 31 (експериментальна) та 23 (контрольна) компоненти. Результати дослідження свідчать, що якісний і кількісний хімічний склад настойок кореневищ із коренями ехінацеї пурпурової характеризується складністю та мінливістю. Це ускладнює процес стандартизації фрітопрепаратів і може впливати на їхню ефективність і безпечність. Тому представники роду ехінацея мають стати об'єктами поглибленого хімічного вивчення.

Висновки. За допомогою ГХ вивчили та здійснили порівняльний аналіз компонентного складу настойок на основі ехінацеї пурпурової (Echinacea purpurea (L.) Moench). Метод ГХ придатний для визначення природних біологічно активних речовин у складі фрітопрепаратів з ехінацеї, його можна використовувати під час розроблення методик стандартизації. Результати дослідження мають цінність для розроблення та вдосконалення аналітичної нормативної документації на сировину та фітопрепарати з ехінацеї пурпурової, а також можуть стати підґрунтям для створення нових субстанцій з імуномодулювальною активністю на основі підземних органів ехінацеї.

Ключові слова: газова хроматографія, ехінацея, компонентний склад, імуномодулювальна дія.

Актуальні питання фрармацевтичної і медичної науки та практики. 2021. Т. 14, № 3(37). С. 275-281

\section{Сравнительное хромато-масс-спектрометрическое исследование настоек на основе Echinacea purpurea (L.) Moench}

Ю. И. Корниевский, Д. Ю. Скорина, В. Г. Корниевская, Н. В. Кандыбей

Актуальной проблемой современности является распространение вторичных иммунодефицитов, связанных с повышенными стрессовыми нагрузками, урбанизацией и негативными изменениями в экологии, приводящими к нарушениям функционирования иммунной системы. Препараты, производимые на основе лекарственных растений, характеризуются более мягким действием, меньшей вероятностью развития привыкания и побочных эффектов, а также возможностью достаточно длительного применения. Эхинацея пурпурная (Echinacea purpurea (L.) Moench), представитель семейства Asteraceae, - перспективное растение с иммуномодулирующим действием. Основными действующими веществами эхинацеи являются фенольные соединения, углеводы и алкиламиды. Химический состав эхинацеи представлен также фрлавоноидами, дубильными веществами, сапонинами, высшими жирными кислотами, аминокислотами, бетаином, эфрирным маслом, макро- и микроэлементами (Se, Co, Ag, Mo, Zn, Mg, K, Na, Fe и др.). Лекарственные препараты проявляют иммуностимулирующее, антиоксидантное, мембраностабилизирующее действие, способствуют заживлению ран, ожогов, язв; их применяют при инфекционных и вирусных заболеваниях, особенно верхних дыхательных путей. Традиционно их используют при фурункулезе, септицемии (заражении крови), пиорее, тонзиллитах, а также для лечения фурункулов, карбункулов и абсцессов. В современной фармацевтической науке ведущее место занимают исследования, связанные с внедрением в медицинскую практику лекарственных средств растительного происхождения, изучением их химического состава, стандартизацией, разработкой оптимальных технологий изготовления фитопрепаратов. Именно поэтому объектами наших исследований стали настойки на основе эхинацеи пурпурной.

Цель работы - изучение и сравнительный анализ компонентного состава настоек на основе эхинацеи пурпурной (Echinacea purpurea (L.) Moench) с помощью газовой хроматографии (ГX).

Материалы и методы. Для исследования использованы настойки корневищ с корнями эхинацеи пурпурной: экспериментальная, изготовленная по промышленной технологической рецептуре (1:5, экстрагент - этанол 70 \%) из сырья, заготовленного в июле 2019 года на опытном участке Запорожского государственного медицинского университета; контрольная - готовая продукция ООО «Житомирская фармацевтическая фабрика», серия 20319. Настойки исследовали на газовом хроматографе Agilent $7890 \mathrm{~B}$ с масс-спектрометрическим детектором 5977В. Для идентификации компонентов использована библиотека масс-спектров NIST14.

Результаты. С помощью ГХ в настойках корневищ с корнями эхинацеи пурпурной идентифицированы 31 (экспериментальная) и 23 (контрольная) компонента. Результаты исследования свидетельствуют, что качественный и количественный химический состав настоек корневищ с корнями эхинацеи пурпурной характеризуется сложностью и изменчивостью. Этот фракт усложняет процесс стандартизации фитопрепаратов и может влиять на их эффективность и безопасность. Поэтому представители рода эхинацея должны стать объектами углубленного химического изучения.

Выводы. С помощью ГХ изучен и проведен сравнительный анализ компонентного состава настоек на основе эхинацеи пурпурной (Echinacea purpurea (L.) Moench). Метод ГX пригоден для определения природных биологически активных веществ в составе фиитопрепаратов из эхинацеи и может быть использован при разработке методик их стандартизации. Результаты исследования имеют ценность для дальнейшей разработки и совершенствования аналитической нормативной документации на сырьё и фитопрепараты из эхинацеи пурпурной, а также могут стать основой для создания новых субстанций с иммуномодулирующей активностью на основе подземных органов эхинацеи.

Ключевые слова: газовая хроматография, эхинацея, компонентный состав, иммуномодулирующее действие.

Актуальные вопросы фрармацевтической и медицинской науки и практики. 2021. Т. 14, № 3(37). С. 275-281 
Today is the actual problem there is a spread of secondary immunodeficiencies, related to high-stress loads, urbanization, and negative changes in ecology, that lead to violations functioning immune system. These states inevitably need it to carry out immune correction. Use for this purpose synthetic drugs complicated a significant risk of developing unwanted reactions and usually low economic availability of such medicines for the population. In return, drugs, which are produced based on medicinal plants, are characteristic with softer action, less likely to get used to it and side effects, as well as the opportunity long enough application $[1,2]$. Therefore, in the practice of rehabilitation of persons with secondary immunodeficiency states, including as support for chemotherapy in cancer, it is advisable to use medicinal plants that have immunotropic effects $[1,3,4]$.

The promising plant with immunomodulatory action is purple Echinacea (Echinacea purpurea (L.) Moench), representative of the family Asteraceae. It is known that phytopreparations based on this plant exhibit immunostimulatory, antioxidant, membrane stabilizing, antiseptic action, and are capable of stimulating the central nervous system [4-10].

It is also important that in modern pharmaceutical science the leading place is occupied with the researches connected with the introduction into medical practice of herbal medicines, studying of their chemical composition, standardization, development of optimum technologies of production of herbal preparations. That is why tinctures based on purple Echinacea have become the object of our research [11].

\section{Aim}

The purpose of the work is to study and comparative analysis of the component composition of tinctures based on purple Echinacea (Echinacea purpurea (L.) Moench) using gas chromatography (GC).

\section{Materials and methods}

Tinctures of rhizomes with purple Echinacea roots were used for the study:

1) experimental - manufactured according to an industrial, technological recipe (1:5, extractant - ethanol $70 \%)$ from raw materials, which was harvested in July 2019 at the experimental site of the Zaporizhzhia State Medical University. The receipt of this tincture was carried out according to validated technology by the approved technological regulations. The main stages of production are reflected in the flow chart (Fig. 1);

2) control - finished products of LLC "Zhytomyr Pharmaceutical Factory", series 20319.

The tinctures were examined on an Agilent 7890B gas chromatograph with a 5977B mass spectrometry detector. Chromatography conditions: DB-5ms column, $30 \mathrm{~m}$ long, with an internal diameter of $250 \mu \mathrm{m}$ and a phase thickness of $0.25 \mu \mathrm{m}$. The carrier gas (helium) velocity is $1.3 \mathrm{ml} / \mathrm{min}$. Injection volume $-0.5 \mu \mathrm{l}$. Flow split $-1: 5$. The temperature of the sample input block is $265^{\circ} \mathrm{C}$. Thermostat temperature: programmable $-70{ }^{\circ} \mathrm{C}$ (holding $1 \mathrm{~min}$ ), up to $150{ }^{\circ} \mathrm{C}$ at a speed of $20^{\circ} \mathrm{C} / \mathrm{min}$ (holding $1 \mathrm{~min}$ ), up to $270{ }^{\circ} \mathrm{C}$ at a speed of $20^{\circ} \mathrm{C} / \mathrm{min}$ (holding $4 \mathrm{~min}$ ). ANIST14 mass spectra library was used to identify the components.

\section{Results}

In the analysis of the obtained chromatograms (Fig. 2, 3, Table 1) and the processing of the results of chromatographic mass spectrometry determination of tincture components on the basis of purple Echinacea Echinacea purpurea (L.) Moench, identified biologically active substances (BAS) belong to derivatives of: carboxylic acids $(2,15,21,22,23)$; esters (4, 17, 26, 27, 34, 35); lactones (6); amides (18, 20, 25, 29); aldehydes (10); ketones $(1,3,5,9)$; glycosides (11); carbocyclic compounds $(31,33,36)$; nitrogen-containing heterocycles $(13,14,16,19,24)$; oxygen-containing heterocycles $(7,8$, $28,30,32,37)$; organosilicon compounds (12).

\section{Discussion}

31 (experimental) and 23 (control) components were identified using GLC in tinctures of rhizomes with purple Echinacea roots. There were 9 components in the experimental tincture:

1) 17.291 Rt pyridine, 4-(3-mercapto-4-methyl-5-(4H-1,2,4 triazolyl))-, $12.14 \%$;

2) 10.503 Rt benzaldehyde, 2-hydroxy-6-methyl-, $7.11 \%$;

3) 12.948 Rt ethyl $\alpha$ - $D$-glucopyranoside, $7.01 \%$;

4) $19.556 \mathrm{Rt} N$-(2-methylbutyl)undeca-(2E,4Z)-diene-8,10-diynamide, $4.60 \%$;

5) 3.51 Rt dihydroxyacetone, $4.15 \%$;

6) $6.53 \mathrm{Rt} 4 H$-pyran-4-one, 2,3-dihydro-3,5-dihydroxy-6-methyl-, $1.59 \%$;

7) 20.459 Rt $1 H$-indene, 2-butyl-3-hexyl-, $1.48 \%$;

8) $8.804 \mathrm{Rt}$ 4-hydroxy-2-methylacetophenone, $1.15 \%$;

9) 22.805 Rt 9,12-octadecadienoic acid (Z,Z)-, 2,3-dihydroxypropyl-, $0.79 \%$.

The control tincture is dominated by 7 components:

1) $22.584 \mathrm{Rt} \gamma$-sitosterol, $17.62 \%$;

2) $17.999 \mathrm{Rt}$ cis-vaccenic acid, $8.37 \%$;

3) $13.064 \mathrm{Rt}$ 1,3,5-cycloheptatriene, 7,7-dimethyl-3-(trimethylsilyl)-, $8.17 \%$;

4) 10.524 Rt benzaldehyde, 2-hydroxy-6-methyl-, 7.8\%; 5) $3.423 \mathrm{Rt}$ dihydroxyacetone, $2.77 \%$;

6) 7.521 Rt benzofuran, 2,3-dihydro-, $1.38 \%$;

7) $19.547 \mathrm{Rt} 2 \mathrm{H}$-pyran-2-one, 6-[2-E-(4-tolyl)ethenyl]-4methoxy-, $1.27 \%$.

In the tinctures studied, there were 15 components in common, with only 2 components in quantitative terms: benzaldehyde, 2-hydroxy-6-methyl- (7.11 \% and $7.80 \%)$ and $2 H$-pyran-2-one, 6-[2- $E$-(4-tolyl)ethenyl]-4-methoxy(1.59\% and $1.27 \%$ ).

The results of the study show that the qualitative and quantitative chemical composition of rhizomes with roots of purple Echinacea was characterized by complexity and variability. This fact complicates the standardization of herbal preparations and may affect their effectiveness and safety. 


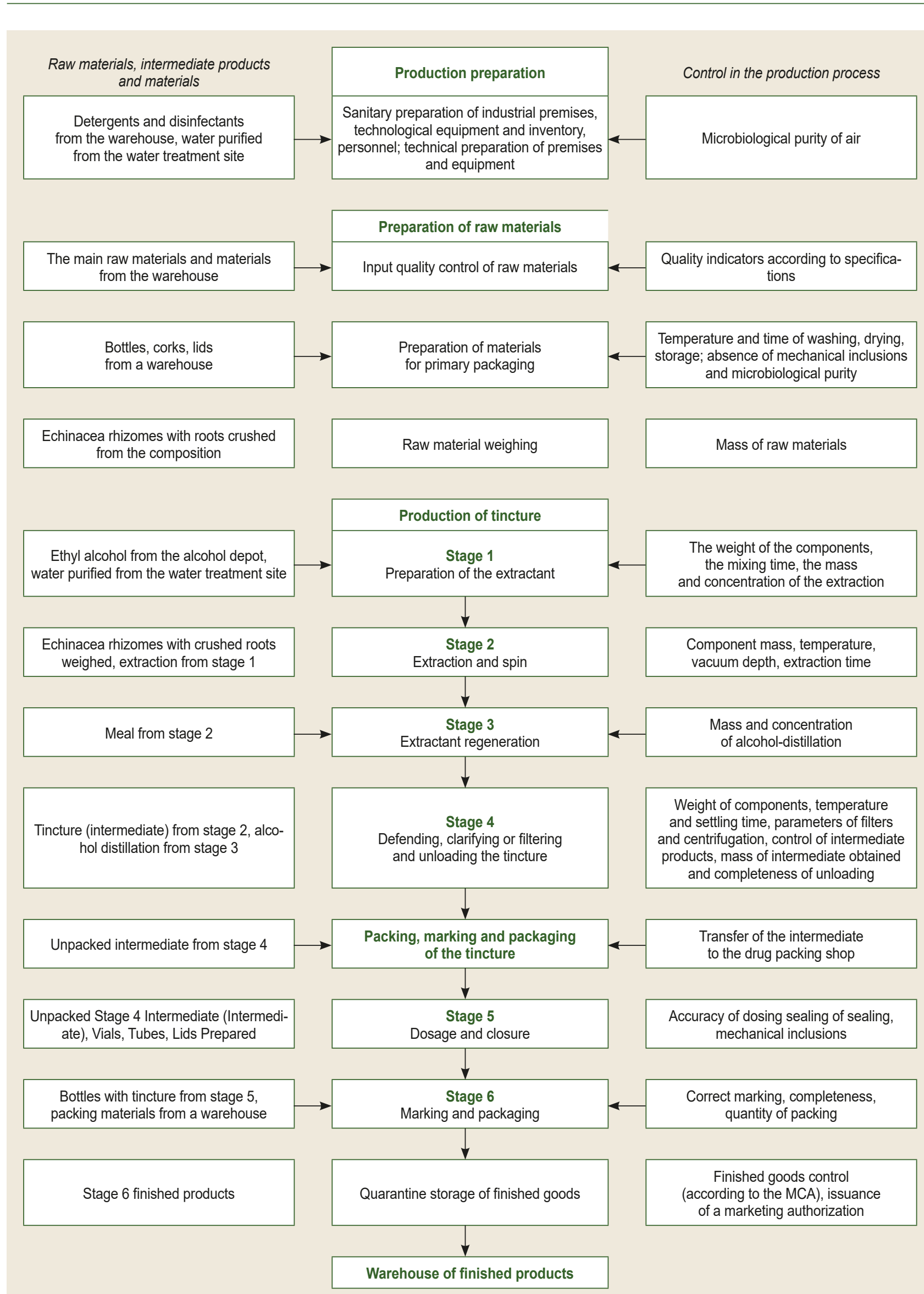

Fig. 1. Technological scheme of production of experimental tincture of rhizomes with purple Echinacea roots. 
2

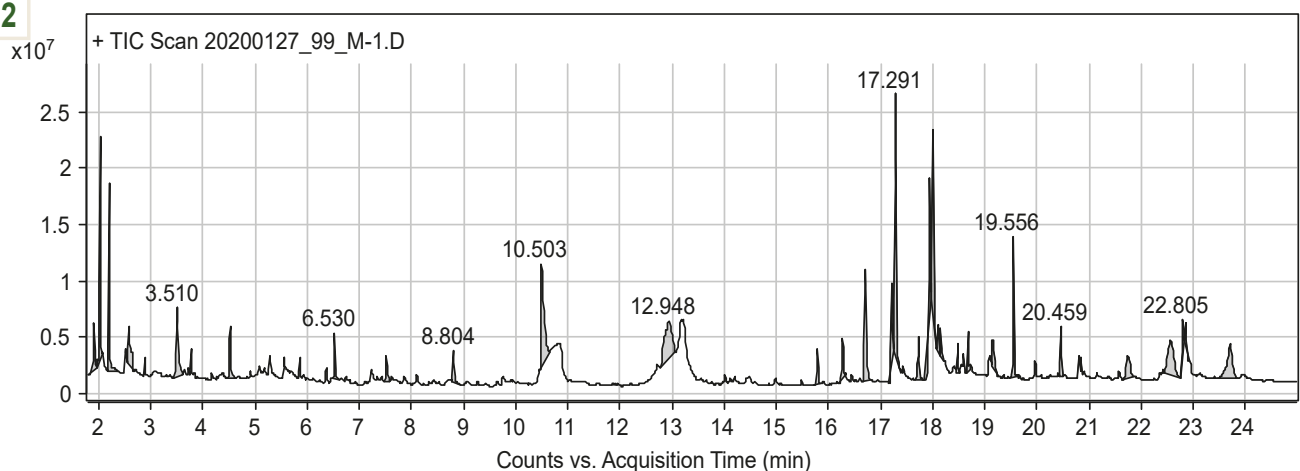

3

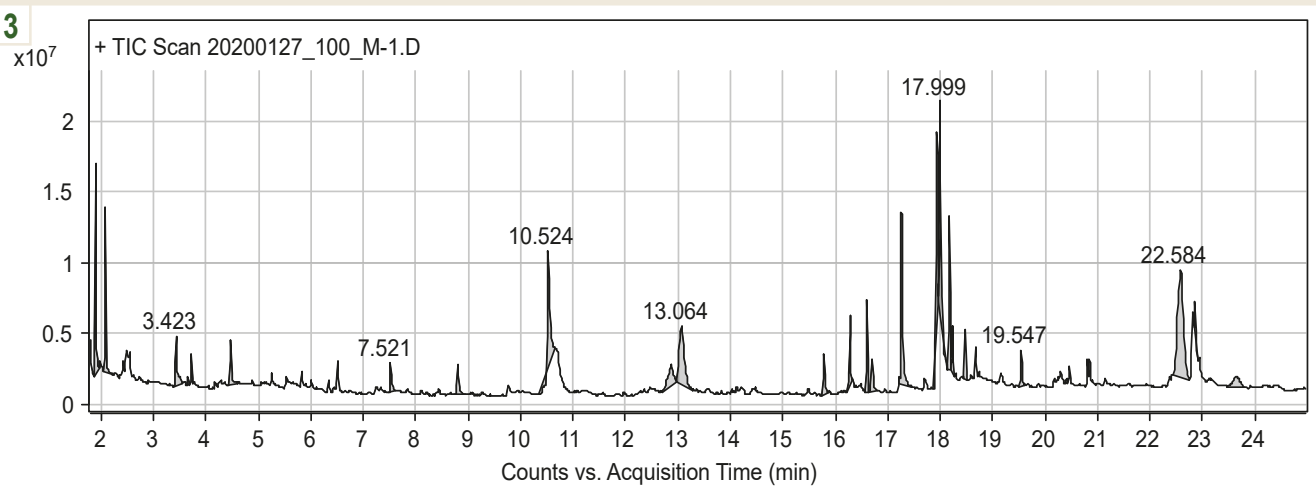

Fig. 2. Chromatogram of experimental tincture of rhizomes with purple Echinacea roots.

Fig. 3. Chromatogram of control tincture of rhizomes with purple Echinacea roots.

Table 1. Comparative chromatographic mass-spectrometric characteristics of tincture components based on purple Echinacea (Echinacea purpurea (L.) Moench)

\begin{tabular}{|c|c|c|c|c|c|c|}
\hline \multirow{3}{*}{ No. } & \multirow{3}{*}{ The name of the component } & \multirow{3}{*}{$\begin{array}{l}\text { Gross } \\
\text { formula }\end{array}$} & \multicolumn{4}{|c|}{ Tinctures of rhizomes with roots of purple Echinacea } \\
\hline & & & \multicolumn{2}{|c|}{ Experimental } & \multicolumn{2}{|l|}{ Control } \\
\hline & & & Rt & Contents, $\%$ & Rt & Contents, $\%$ \\
\hline 1. & Acetone & $\mathrm{C}_{3} \mathrm{H}_{6} \mathrm{O}$ & 1.906 & 1.65 & - & - \\
\hline 2. & Acetic acid & $\mathrm{C}_{2} \mathrm{H}_{4} \mathrm{O}_{2}$ & 2.022 & 5.73 & 1.89 & 5.31 \\
\hline 3. & 2-Propanone, 1-hydroxy & $\mathrm{C}_{3} \mathrm{H}_{6} \mathrm{O}_{2}$ & 2.199 & 4.30 & 2.082 & 3.72 \\
\hline 4. & Propanoic acid, 2-oxo-, methyl ester & $\mathrm{C}_{4} \mathrm{H}_{6} \mathrm{O}_{3}$ & 2.584 & 2.42 & - & - \\
\hline 5. & Dihydroxyacetone & $\mathrm{C}_{3} \mathrm{H}_{6} \mathrm{O}_{3}$ & 3.51 & 4.15 & 3.423 & 2.77 \\
\hline 6. & 2-Hydroxy-y-butyrolactone & $\mathrm{C}_{4} \mathrm{H}_{6} \mathrm{O}_{3}$ & 4.524 & 2.24 & 4.467 & 1.74 \\
\hline 7. & 4H-Pyran-4-one, 2,3-dihydro-3,5-dihydroxy-6 methyl- & $\mathrm{C}_{6} \mathrm{H}_{8} \mathrm{O}_{4}$ & 6.53 & 1.59 & - & - \\
\hline 8. & Benzofuran, 2,3-dihydro & $\mathrm{C}_{8} \mathrm{H}_{8} \mathrm{O}$ & 7.523 & 0.94 & 7.521 & 1.38 \\
\hline 9. & 4-Hydroxy-2methyl acetophenone & $\mathrm{C}_{9} \mathrm{H}_{10}$ & 8.804 & 1.15 & 8.804 & 1.43 \\
\hline 10. & Benzaldehyde, 2-hydroxy-6-methyl- & $\mathrm{C}_{8} \mathrm{H}_{8} \mathrm{O}_{2}$ & 10.503 & 7.11 & 10.524 & 7.80 \\
\hline 11. & Ethyl $\alpha$ - $D$-glucopyranoside & $\mathrm{C}_{8} \mathrm{H}_{16} \mathrm{O}_{6}$ & 12.948 & 0.01 & 12.869 & 2.98 \\
\hline 12. & 1,3,5-Cycloheptatriene, 7,7-dimethyl-3-(trimethylsilyl)- & $\mathrm{C}_{12} \mathrm{H}_{20} \mathrm{Si}$ & - & - & 13.064 & 8.17 \\
\hline 13. & 4(1H)-Quinazolinone, 2,3-dihydro-1,3-dimethyl-2-thioxo- & $\mathrm{C}_{10} \mathrm{H}_{10} \mathrm{~N}_{2} \mathrm{~S}$ & - & - & 15.787 & 1.54 \\
\hline 14. & (1H)-Quinolin-4-ol-2-one, 8-nitro- & $\mathrm{C}_{9} \mathrm{H}_{6} \mathrm{~N}_{2} \mathrm{O}_{4}$ & 15.787 & 1.23 & - & - \\
\hline 15. & $n$-Hexadecanoic acid & $\mathrm{C}_{16} \mathrm{H}_{32} \mathrm{O}_{2}$ & 16.277 & 1.52 & 16.284 & 2.75 \\
\hline 16. & 1,2,4-Triazole, 3-mercapto-4-phenyl-5-methyl- & $\mathrm{C}_{9} \mathrm{H}_{9} \mathrm{~N}_{3} \mathrm{~S}$ & 16.71 & 5.27 & 16.695 & 1.85 \\
\hline 17. & Hexadecanoic acid, ethyl ester & $\mathrm{C}_{18} \mathrm{H}_{36} \mathrm{O}_{2}$ & - & - & 16.598 & 2.7 \\
\hline 18. & N-Isobutylundeca-(2E,4E)-diene-8,10-diynamide & $\mathrm{C}_{15} \mathrm{H}_{19} \mathrm{NO}$ & 17.218 & 1.93 & - & - \\
\hline
\end{tabular}


Cont. of Table 1.

\begin{tabular}{|c|c|c|c|c|c|c|}
\hline \multirow{3}{*}{ No. } & \multirow{3}{*}{ The name of the component } & \multirow{3}{*}{$\begin{array}{l}\text { Gross } \\
\text { formula }\end{array}$} & \multicolumn{4}{|c|}{ Tinctures of rhizomes with roots of purple Echinacea } \\
\hline & & & \multicolumn{2}{|c|}{ Experimental } & \multicolumn{2}{|l|}{ Control } \\
\hline & & & Rt & Contents, $\%$ & Rt & Contents, $\%$ \\
\hline 19. & Pyridine,4-(3-mercapto-4-methyl-5-(4H-1,2,4 triazolyl))- & $\mathrm{C}_{8} \mathrm{H}_{8} \mathrm{~N}_{4} \mathrm{~S}$ & 17.291 & 12.14 & 17.267 & 9.20 \\
\hline 20. & $N$-Isobutylundeca-(2E,4E)-diene-8,10-diynamide & $\mathrm{C}_{15} \mathrm{H}_{19} \mathrm{NO}$ & $\begin{array}{l}17.731 \\
18.106\end{array}$ & $\begin{array}{l}1.91 \\
0.86\end{array}$ & - & - \\
\hline 21. & 9,12-Octadecadienoic acid $(Z, Z)-$ & $\mathrm{C}_{18} \mathrm{H}_{32} \mathrm{O}_{2}$ & 17.947 & 4.2 & 17.943 & 7.73 \\
\hline 22. & cis-Vaccenic acid & $\mathrm{C}_{18} \mathrm{H}_{34} \mathrm{O}_{2}$ & - & - & 17.999 & 8.37 \\
\hline 23. & 9-Octadecenoic acid, $(E)$ - & $\mathrm{C}_{18} \mathrm{H}_{34} \mathrm{O}_{2}$ & 18.004 & 8.01 & - & - \\
\hline 24. & Dicyclooctanopyridazine & $\mathrm{C}_{16} \mathrm{H}_{24} \mathrm{~N}_{2}$ & 18.158 & 1.03 & - & - \\
\hline 25. & $N$-lsobutyl-(2E,4Z,8Z,10E)-dodecatetraenamide & $\mathrm{C}_{16} \mathrm{H}_{25} \mathrm{NO}$ & \begin{tabular}{|l}
18.48 \\
18.68
\end{tabular} & $\begin{array}{l}0.93 \\
1.27\end{array}$ & 18.476 & 2.04 \\
\hline 26. & Linoleic acid, ethyl ester & $\mathrm{C}_{20} \mathrm{H}_{36} \mathrm{O}_{2}$ & - & - & 18.175 & 4.96 \\
\hline 27. & 9,12,15-Octadecatrienoic acid, ethyl ester, (Z,Z,Z)- & $\mathrm{C}_{20} \mathrm{H}_{34} \mathrm{O}_{2}$ & - & - & 18.233 & 1.29 \\
\hline 28. & 2H-Pyran-2-one, 6-[2-E-(4-tolyl)ethenyl]-4methoxy- & $\mathrm{C}_{15} \mathrm{H}_{14} \mathrm{O}_{3}$ & - & - & 19.547 & 1.27 \\
\hline 29. & $N$-(2-Methylbutyl)undeca-(2E,4Z)-diene-8,10 diynamide & $\mathrm{C}_{16} \mathrm{H}_{21} \mathrm{NO}$ & 19.556 & 4.60 & - & - \\
\hline 30. & 2H-Pyran-2-one, 6-[2-E-(4-tolyl)ethenyl]-4methoxy- & $\mathrm{C}_{15} \mathrm{H}_{14} \mathrm{O}_{3}$ & - & - & 19.547 & 1.27 \\
\hline 31. & 1H-Indene, 2-butyl-3-hexyl- & $\mathrm{C}_{19} \mathrm{H}_{28}$ & 20.459 & 1.48 & - & - \\
\hline 32. & $\beta$-Tocopherol & $\mathrm{C}_{28} \mathrm{H}_{48} \mathrm{O}_{2}$ & 21.743 & 2.14 & - & - \\
\hline 33. & y-Sitosterol & $\mathrm{C}_{29} \mathrm{H}_{50} \mathrm{O}$ & 22.564 & 5.28 & 22.584 & 17.62 \\
\hline 34. & 9,12-Octadecadienoic acid (Z,Z)-, 2,3-dihydroxypropyl ester & $\mathrm{C}_{21} \mathrm{H}_{38} \mathrm{O}$ & 22.805 & 0.79 & - & - \\
\hline 35. & 9-Octadecenoic acid (Z)-, 2,3-dihydroxypropyl ester & $\mathrm{C}_{21} \mathrm{H}_{40} \mathrm{O}_{4}$ & 22.856 & 0.85 & 22.856 & 1.35 \\
\hline 36. & $\beta$-Amyrin & $\mathrm{C}_{30} \mathrm{H}_{50} \mathrm{O}$ & - & - & 23.642 & 2.04 \\
\hline 37. & d,l-a-Tocopherol & $\mathrm{C}_{29} \mathrm{H}_{50} \mathrm{O}_{2}$ & 23.705 & 4.65 & - & - \\
\hline
\end{tabular}

Therefore, representatives of the genus Echinacea should be the object of further advanced chemical study.

\section{Conclusions}

1. A comparative analysis of the component composition of tinctures based on purple Echinacea was studied and performed using GC (Echinacea purpurea (L.) Moench). The GC method was suitable for the determination of natural BAS in the composition of Echinacea herbal preparations and can be used in the development of methods for their standardization.

2. In the experimental tincture of rhizomes with roots of purple Echinacea identified 31 components, and in the control-23. The composition of the tinctures was characterized by complexity and variability. In the tinctures studied, 15 components were common, with only 2 components in quantitative terms.

3. The results of the study were of value for the further development and improvement of analytical regulatory documentation for raw materials and herbal preparations of purple Echinacea. They may also be the basis for the creation of new immunomodulatory substances based on the underground organs of Echinacea.
Prospects for further research. Tinctures based on Echinacea purpurea (L.) Moench can be considered as a basis for the creation of new substances with immunomodulatory activity based on the underground organs of echinacea.

\section{Funding}

The work is part of the joint integrated work of the Department of Pharmacognosy, Pharmacology and Botany of Zaporizhzhia State Medical University.

Conflicts of interest: authors have no conflict of interest to declare. Конфолікт інтересів: відсутній.

Information about authors:

Korniievskyi Yu. I., PhD, Associate Professor of the Department of Pharmacognosy, Pharmacology and Botany, Zaporizhzhia State Medical University, Ukraine.

ORCID ID: 0000-0001-7863-6736

Skoryna D. Yu., PhD, Senior Lecturer of the Department

of Pharmaceutical Chemistry, Zaporizhzhia State Medical University, Ukraine.

ORCID ID: 0000-0002-8851-8757

Korniievska V. H., PhD, Associate Professor of the Department of Pharmacognosy, Pharmacology and Botany, Zaporizhzhia State Medical University, Ukraine.

ORCID ID: $\underline{0000-0001-8307-1282}$ 
Kandybei N. V., PhD, Teaching Assistant of the Department of Clinical Pharmacy, Pharmacotherapy, Management and Organization of Pharmacy of FPE, Zaporizhzhia State Medical University, Ukraine.

Відомості про авторів:

Корнієвський Ю. І., канд. фарм. наук, доцент каф. фрармакогнозії, фрармакології та ботаніки, Запорізький державний медичний університет, Україна.

Скорина Д. Ю., канд. фарм. наук, старший викладач каф. фрармацевтичної хімії, Запорізький державний медичний університет, Україна.

Корнієвська В. Г., канд. фрарм. наук, доцент каф. фрармакогнозії, фрармакології та ботаніки, Запорізький державний медичний університет, Україна.

Кандибей Н. В., канд. фрарм. наук, асистент каф. клінічної фармації, фармакотерапії та УЕФ ФПО, Запорізький державний медичний університет; директор з якості, ПрАТ Фармацевтична фрабрика «ВІОЛА», м. Запоріжжя, Україна.

\section{Сведения об авторах:}

Корниевский Ю. И., канд. фрарм. наук, доцент каф. фрармакогнозии, фармакологии и ботаники, Запорожский государственный медицинский университет, Украина.

Скорина Д. Ю., канд. фрарм. наук, старший преподаватель каф. фрармацевтической химии, Запорожский государственный медицинский университет, Украина.

Корниевская В. Г., канд. фрарм. наук, доцент каф. фрармакогнозии, фармакологии и ботаники, Запорожский государственный медицинский университет, Украина.

Кандыбей Н. В., канд. фрарм. наук, ассистент каф. клинической фармации, фармакотерапии и УЭФ ФПО, Запорожский государственный медицинский университет; директор по качеству ЧАО Фармацевтическая фабрика «ВІОЛА», г. Запорожье, Украина.

\section{References}

[1] Korniievskyi, Yu. I., Panasenko, O. I., Korniievska, V. H., Fursa, M. S Bohuslavska, N. Yu., Parchenko, V. V., \& Kaplaushenko, A. H. (2012). Zelena apteka [Green pharmacy]. Zaporizhzhia: Karat. [in Ukrainain]

[2] Kolesnyk, Yu. M., Korniievskyi, Yu. I., \& Panasenko, O. I. (2013). Liky Khortytsi [Medicines of Khortytsia]. Zaporizhzhia: ZSMU. [in Ukrainain].

[3] Korniievskyi, Yu. I., Bohuslavska, N. Yu., Korniievska, V. H., Bibyk, L. H., Panchenko, S. V., \& Shevchenko, A. I. (2016). Fitoterapiia $v$ onkolohii [Phytotherapy in oncology]. Zaporizhzhia: ZSMU. [in Ukrainain].

[4] Kryvenko, V. I., Korniievskyi, Yu. I., Kolesnyk, M. Yu., Pakhomova, S. P., Fedorova, O. P., Bohuslavska, N. Yu., Korniievska, V. H., \& Panchenko, S. V. (2015). Fitoterapiia v praktytsi simeinoho likaria [Phytotherapy in the practice of a family doctor]. Zaporizhzhia: ZSMU, 2015. [in Ukrainian].

[5] Korniievskyi, Yu. I., Rossikhin, V. V., Serbin A. H., Skoryna, D. Yu. Korniievska, V. H., \& Bohuslavska, N. Yu. (2019). Vitaminy v roslynnomu sviti [Vitamins in the Flora]. Zaporizhzhia: ZSMU. [in Ukrainian].

[6] Korniievskyi, Yu. I., Bohuslavska, N. Yu., Krut, Yu. Ya., Korniievska, V. H., Omelianchyk, L. O., \& Lutsenko, N. S. (2014). Fitoterapiia $v$ akusherstvi ta hinekolohii Zaporizhzhia: Karat. [in Ukrainian].

[7] Korniievskyi, Yu. I., Kraidashenko, O. B., Krasko, M. P., Bohuslavska, N. Yu., Korniievska, V. H., \& Opryshko, B. I. (2017). Fitoterapiia $\checkmark$ kardiolohii [Phytotherapy in cardiology]. Zaporizhzhia: ZSMU. [in Ukrainain].

[8] Kolesnyk, Yu. M., Bachurin, H. V., Serbin, A. H., Korniievskyi, Yu. I, \& Omelianchyk, L. O. (2014). Fitoterapiia v urolohii [Phytotherapy in urology] Zaporizhzhia: ZSMU, 2014.

[9] Manayi, A., Vazirian, M., \& Saeidnia, S. (2015). Echinacea purpurea: Pharmacology, phytochemistry and analysis methods. Pharmacognosy reviews, 9(17), 63-72. https://doi.org/10.4103/0973-7847.156353

[10] Matthias, A., Banbury, L., Bone, K. M., Leach, D. N., \& Lehmann, R. P. (2008). Echinacea alkylamides modulate induced immune responses in T-cells. Fitoterapia, 79(1), 53-58. https://doi. org/10.1016/j,fitote.2007.07.012

[11] State Enterprise Ukrainian Scientific Pharmacopoeial Center of Medicines Quality. (2011). Derzhavna Farmakopeia Ukrainy. Dopovnennia 4 [The State Pharmacopoeia of Ukraine] (1st ed., Suppl. 4). Kharkiv: Naukovo-ekspertnyi farmakopeinyi tsentr. [in Ukrainian]. 